\title{
Kevätviljapeltojen rikkakasvien runsauden muutokset
}

\author{
Terho Hyvönen ${ }^{1)}$, Jukka Salonen ${ }^{2)}$ ja Elise Ketoja ${ }^{3)}$ \\ ${ }^{1)}$ MTT, Kasvinsuojelu, 31600 Jokioinen, terho.hyvonen@mtt.fi \\ ${ }^{2)}$ MTT, Kasvinsuojelu, 31600 Jokioinen, jukka.salonen@mtt.fi \\ ${ }^{3)}$ MTT, Tietopalveluyksikkö, 31600 Jokioinen, elise.ketoja@mtt.fi
}

\section{Johdanto}

Viljelymenetelmien tehostuminen, erityisesti lisääntynyt lannoitus ja torjunta-aineiden pitkäaikainen käyttö, on vähentänyt viljapeltojen rikkakasviyhteisöjen lajiston monimuotoisuutta ja muuttanut lajien runsaussuhteita. Suomessa kevätviljapeltojen rikkakasvien tiheyden ja kuivapainon havaittiin laskeneen 1960-luvulta 1980-luvulle (Mukula ym. 1969, Erviö \& Salonen 1987). Vähentyneitä lajeja olivat useat nurmikierrossa yleiset monivuotiset lajit ja happamilla mailla viihtyvä peltohatikka. Runsastuneita lajeja olivat juolavehnä ja jotkut MCPA:lle vastustuskykyiset lajit, kuten pelto-orvokki ja peltoemäkki. Keskeisiä rikkakasviyhteisöjä muokanneita muutoksia suomalaisessa viljanviljelyssä 1990luvulla ovat olleet laajamittainen kesannointi (vuosina 1990-1995), luomuviljelyn yleistyminen $(0,3$ :sta 6,3 prosenttiin viljelyalasta 90 -luvun aikana) sekä siirtyminen fenoksihappopohjaisten torjunta-aineiden käytöstä pienannosherbisideihin eli sulfonyyliureoihin, joita käytetään nykyisin noin puolella ruiskutetuista kevätviljapelloista.

Tutkimme, kuinka viimeaikaiset muutokset maataloudessa ovat vaikuttaneet kevätviljapeltojen rikkakasviyhteisöjen yksilömäärään ja kuivapainoon, lajien runsaussuhteisiin ja lajiston monimuotoisuuteen. Vertailimme 1980- ja 1990-lukuja, joiden välillä keskeiset muutokset olivat torjunta-aineiden käytön muutos ja luomuviljelyn yleistyminen. Oletimme luomuviljelyn lisäävän rikkakasvien yksilömäärää ja kuivapainoa, lajimäärää sekä torjunta-aineille herkkien lajien runsautta. Sulfonyyliureoiden käytön yleistymisen oletimme lisäävän niille vastustuskykyisten lajien, kuten peltomataran ja peltoorvokin, runsautta. Tutkimusaineistonamme olivat vuosina 1961-1964 (Mukula ym. 1969), 1982-1984 (Erviö \& Salonen 1987) ja 1997-1999 (Salonen ym. 2001) MTT:n tekemät kevätviljapeltojen rikkakasvikartoitukset.

\section{Aineisto ja menetelmät}

Torjunta-aineiden käytön muutosten vaikutusten tutkimiseen käytettiin aineistoa valtakunnallisesta rikkakasvikartoituksesta, sen sijaan luomuviljelyn ja tavanomaisen viljelyn vertailuun käytettiin sekä kartoitusaineistoa että erikseen tehdyn viljelymenetelmävertailun aineistoa.

Kartoituksen näytteet kerättiin kuudeltatoista alueelta Etelä- ja Keski-Suomesta vuosina 19971999. Kartoitukseen pyrittiin saamaan mukaan mahdollisimman monta aikaisemmissa kartoituksissa tutkituista lohkoista. Tutkimuksessa oli mukana 690 kevätviljalohkoa ja 305 maatilaa, joiden tuotantomuotona oli joko tavanomainen tai luonnonmukainen tuotanto ja tuotantosuuntana joko kasvin- tai kotieläintuotanto. Tutkituista pelloista 165 oli luomuviljelyssä ja 525 tavanomaisessa viljelyssä. Tavanomaisesti viljellyistä lohkoista 457 oli ruiskutettu rikkakasvien torjunta-aineella tutkimusvuonna ja 68 oli jäänyt tai jätetty ruiskuttamatta. Näytteet kerättiin neljän viikon aikana alkaen heinäkuun puolivälistä. Kullekin peltolohkolle sijoitettiin satunnaisesti kymmenen $0,1 \mathrm{~m}^{2}: \mathrm{n}$ näytealaa, joilta rikkakasvit laskettiin lajeittain. Neljältä näytealalta otettiin lisäksi biomassanäyte, josta määritettiin kuivapaino. Taustatietoja viljelymenetelmistä kerättiin haastattelemalla viljelijöitä.

Torjunta-aineiden käytön muutosten tutkimiseen 1980- ja 1990-lukujen välillä käytettiin aineistoa lohkoilta, jotka oli tutkittu molempina vuosikymmeninä ja jotka oli ruiskutettu torjuntaaineella tutkimusvuonna. Tällaisia lohkoja oli 80, ja ne sijaitsivat kymmenellä tutkimusaluella. Näillä lohkoilla käytetyt torjunta-aineet voitiin luokitella seuraavasti: MCPA (23 lohkoa 80-luvulla ja 11 lohkoa 90-luvulla), MCPA+fenoksihappo (52 ja 20), sulfonyyliureat (2 ja 39), sulfonyyliurea+fenoksihappo (0 ja 9) ja muu (3 ja 1). Vuosikymmenten välillä vertailtiin rikkakasvien kokonaisyksilömäärän ja -kuivapainon eroja sekä runsaimpien lajien yksilömäärän ja -kuivapainon eroja.

Kartoitusaineistoa käytettiin rikkakasvien kokonaisyksilömäärän ja -kuivapainon sekä lajimäärän vertailuun luomuviljelyn ja tavanomaisen viljelyn välillä. Erityinen viljelymenetelmien vertailuaineisto kerättiin vuosina 1997-1999 Lammin ja Jokioisten ympäristössä. Vertailuaineistoa käytettiin yksityiskohtaisempaan lajimäärien ja lajiston koostumuksen vertailuun. Aineisto kerättiin samalla peltoaukella sijainneilta luomutilan sekä tavanomaisesti viljellyn karja- ja viljatilan kevätvil- 
jalohkoilta. Lammin alueella tällaisia peltoaukeita oli kuusi, sen sijaan Jokioisten alueella löydettiin 17 luomun ja tavanomaisen viljelyn vertailuparia. Kultakin tilalta pyrittiin saamaan mukaan neljä tutkimuslohkoa, mutta tutkittujen lohkojen määrä vaihteli vuosittain johtuen viljelykierrosta. Pellot tutkittiin touko-kesäkuussa (ennen tavanomaisesti viljeltyjen lohkojen mahdollisia torjuntaaineruiskutuksia) ja heinä-elokuussa (ruiskutusten jälkeen). Lammin alueen tilat olivat jo ohittaneet luomusiirtymäkauden, mutta useimmat Jokioisten alueen tilat olivat nuorempia luomutiloja. Kullekin peltolohkolle sijoitettiin satunnaisesti kymmenen $0,1 \mathrm{~m}^{2}:$ n näytealaa, joilta rikkakasvit laskettiin lajeittain. Lajimäärän eroja viljelymenetelmien välillä vertailtiin kovarianssianalyysillä, jossa kovariaattina käytettiin rikkakasvien yksilömäärää, koska laji- ja yksilömäärän välillä havaittiin positiivinen riippuvuus. Touko-kesäkuun ja heinä-elokuun aineistot analysoitiin erikseen.

\section{Tulokset}

Kartoituksessa löydettiin yhteensä 160 rikkakasvilajia. Keskimääräinen lajimäärä oli ruiskuttamattomilla tavanomaisilla lohkoilla yhtä lajia suurempi luomupeltoihin verrattuna (Taulukko 1). Ruiskutettujen tavanomaisten peltojen ja luomupeltojen lajimäärien ero oli noin kymmenen lajia. Rikkakasvien keskimääräinen yksilömäärä ja kuivapaino olivat luomupelloilla suurempia kuin ruiskuttamattomilla tavanomaisilla lohkoilla.

Taulukko 1. Rikkakasvien keskimääräinen lajimäärä (vaihteluväli suluissa), yksilömäärä (mediaani suluissa) ja kuivapaino (mediaani suluissa) 1960-, 1980- ja 1990-luvun rikkakasvikartoituksissa. Ei. ruisk = lohkoja ei ruiskutettu torjunta-aineella tutkimusvuonna ja Ruisk. = lohkot ruiskutettu torjunta-aineella tutkimusvuonna.

1960-1 1980-1

$1990-1$

\begin{tabular}{ccc}
\cline { 3 - 3 } Tavanomainen Luomu & $\begin{array}{l}\text { Kaikki } \\
\text { lohkot }\end{array}$
\end{tabular}

Ei ruisk. Ruisk. Ei ruisk. Ruisk. Ei ruisk.

\begin{tabular}{lccccccc}
\hline & & & & & & & \\
Tutkimuslohkoja & 2710 & 260 & 267 & 457 & 68 & 165 & 690 \\
Lajeja/lohko & - & - & - & $15(2-45)$ & $25(7-38)$ & $24(11-44)$ & 18 \\
Yksilöm. (yks./m²) & 550 & - & $173(124)$ & $136(91)$ & $420(374)$ & $469(395)$ & $243(160)$ \\
Kuivapaino (kg/ha) & 1000 & 124 & $320(183)$ & $163(63)$ & $605(413)$ & $678(567)$ & $329(141)$
\end{tabular}

Luomun ja tavanomaisen vertailuaineistossa rikkakasvien kokonaislajimäärä oli luomupelloilla suurempi kuin tavanomaisesti viljellyillä pelloilla sekä touko-kesäkuussa (luomu 55 lajia, tavanomainen vilja 46 ja tavanomainen karja 48) että heinä-elokuussa (71 vs 55 ja 57). Yksilömäärän suhteen korjattu (tai vakioitu) keskimääräinen lajimäärä oli luomupelloilla touko-kesäkuussa kolme ja heinäelokuussa kuusi lajia korkeampi verrattuna tavanomaisiin peltoihin (Taulukko 2). Tavanomaisesti viljeltyjen vilja- ja karjatilojen peltojen lajimäärät eivät eronneet keskenään kummallakaan näytteenottokerralla.

Touko-kesäkuussa keskimääräinen yksilömäärän suhteen korjattu lajimäärä erosi vuosien välillä $\left(\mathrm{F}_{2,35.9}=5.37\right.$, $\left.\mathrm{p}=0.01\right)$, keskiarvojen ollessa $12.0,14.0$ ja 12.6 vuosina 1997, 1998 ja 1999 (keskiarvon keskivirhe $=0.5$ ). Lajimäärän vuosivaihtelusta huolimatta viljelymenetelmien väliset erot eivät olleet riippuvaisia vuodesta $\left(\mathrm{F}_{4,30.1}=1.16, \mathrm{p}=0.35\right.$ viljelymenetelmän ja vuoden yhdysvaikutus, ja $\mathrm{F}_{2}$, 29.9=12.05, p<0.001 viljelymenetelmän päävaikutus). Heinä-elokuussa korjatut keskiarvot (sekä keskiarvon keskivirhe) vuosina 1997, 1998 ja 1999 olivat 12.2 (0.4), 12.3 (0.7) ja 10.2 (0.7) tavanomaisille lohkoille, ja 18.7 (0.8), 18.9 (1.0) sekä 14.6 (1.1) luomupelloille.

Molemmissa viljelymenetelmissä runsaita lajeja olivat jauhosavikka, peltohatikka, pillikkeet, pihatähtimö, ukontatar, juolavehnä ja pelto-orvokki. Touko-kesäkuussa lajien runsausjakauma oli molemmissa viljelymenetelmissä samankaltainen. Sen sijaan heinä-elokuussa torjunta-aineille herkkien lajien osuus pieneni tavanomaisilla pelloilla, jolloin pelto-orvokin, pihatähtimön ja juolavehnän suhteelliset runsaudet kasvoivat. Luomupelloilla molempina tutkimusajankohtina dominoivat samat lajit (erityisesti jauhosavikka). 
Taulukko 2. Yksilömäärän suhteen korjattujen lajimääräkeskiarvojen vertailu viljelymenetelmien välillä. $L$ viittaa luomuviljelyyn, TV tavanomaiseen viljanviljelyyn ja TK tavanomaiseen karjatalouteen. Heinäelokuussa ei viljelymenetelmien välistä eroa testattu, koska ero oli ilmeinen.

\begin{tabular}{|c|c|c|c|c|c|c|c|}
\hline $\begin{array}{l}\text { Ajan- } \\
\text { kohta }\end{array}$ & $\begin{array}{c}\text { Viljely- } \\
\text { menetelmä }\end{array}$ & $\begin{array}{l}\text { Korjattu } \\
\text { keskiarv } \\
\text { o }\end{array}$ & $\begin{array}{l}\text { 95\%:n } \\
\text { luottamus- } \\
\text { välit }\end{array}$ & Vertailu & $\begin{array}{l}\text { Korjattujen } \\
\text { keskiarvojen } \\
\text { erotus }\end{array}$ & $\begin{array}{c}\text { 95\%:n } \\
\text { luotta- } \\
\text { musvälit }\end{array}$ & $\begin{array}{l}\text { Erojen tilas- } \\
\text { tollinen } \\
\text { merkitsevyys }\end{array}$ \\
\hline \multirow{3}{*}{$\begin{array}{l}\text { Touko- } \\
\text { kesäkuu }\end{array}$} & $\mathrm{L}$ & 14.9 & $(13.8,16.1)$ & $L-T V$ & 3.3 & $(1.9,4.8)$ & $* * *$ \\
\hline & TV & 11.6 & $(10.6,12.6)$ & $\mathrm{L}-\mathrm{TK}$ & 2.9 & $(1.4,4.4)$ & $* * *$ \\
\hline & TK & 12.0 & $(10.9,13.1)$ & TK - TV & 0.4 & $(-1.0,1.9)$ & o \\
\hline \multirow{3}{*}{$\begin{array}{l}\text { Heinä- } \\
\text { elokuu }\end{array}$} & $\mathrm{L}$ & 17.4 & $(15.5,19.3)$ & $\mathrm{L}-\mathrm{TV}$ & 5.9 & - & ei \\
\hline & TV & 11.5 & $(10.3,12.7)$ & $\mathrm{L}-\mathrm{TK}$ & 5.7 & - & testattu \\
\hline & TK & 11.7 & $(10.5,12.9)$ & $\mathrm{TK}-\mathrm{TV}$ & 0.2 & $(-1.4,1.9)$ & 0 \\
\hline
\end{tabular}

Torjunta-aineiden käytön muutosten tutkimuksessa rikkakasvien keskimääräinen kuivapaino oli 90luvulla $31.1 \mathrm{~kg} / \mathrm{ha}$ suurempi kuin 80-luvulla ( $\mathrm{p}=0.01,95 \%$ luottamusväli: 7.2-55.0). Peltolohkojen välinen vaihtelu kuivapainoissa selitti kokonaisvaihtelusta $63 \%$, tutkimustilojen välinen vaihtelu $37 \%$ ja alueiden välinen vaihtelu $0 \%$. Rikkakasvien yksilömäärän kokonaisvaihtelusta tutkimusalueet selittivät $25 \%$, tilat $18 \%$ ja lohkot $57 \%$. Alueitten välinen vaihtelu oli tilastollisesti merkitsevä $\left(\chi^{2}(1)=5.8, p=0.01\right)$. Neljällä tutkimusalueella (Nauvo, Laukaa, Laihia ja Nivala) rikkakasvien suurempi yksilömäärä 1990-luvulla oli tilastollisesti merkitsevä, ja kolmella alueella (Paimio, Tammela ja Kitee/Mikkeli) oli tendenssiä samansuuntaisesta erosta $(\mathrm{p}<0.14)$. Kahdella alueella (Laitila, Nurmijärvi) tiloja olisi pitänyt olla enemmän luotettavien päätelmien tekemiseksi. Peltolohkojen välistä vaihtelua yritettiin selittää taustamuuttujien (torjunta-aineiden käyttövuosien määrä, torjunta-aineen muutos, lannoitusmäärä, viljelykasvi, viljelykierto, maaperän happamuus) avulla, mutta ne eivät selittäneet vaihtelua sen jälkeen, kun alue ja tila olivat selittäjinä.

Lajien runsaudessa havaittiin vain pieniä eroja 1980- ja 1990-lukujen välillä. Pelto-orvokki, peltomatara, jauhosavikka ja juolavehnä olivat hieman runsastuneet, ja pillikkeet sekä linnunkaali vähentyneet. Jauhosavikan ja peltomataran esiintymisfrekvenssit olivat kasvaneet yli 25\%, kun taas pillikkeiden esiintymisfrekvenssi oli pienentynyt $10 \%$.

\section{Tulosten tarkastelu}

Luomuviljelyn vaikutukset kevätviljapeltojen rikkakasviyhteisöön olivat odotustemme mukaisia: luomuviljely lisäsi rikkakasvien yksilö- ja lajimäärää, kuivapainoa, sekä torjunta-aineille herkkien lajien runsautta. Vertailututkimuksessa havaitut lajimäärien erot luomupeltojen ja tavanomaisesti viljeltyjen peltojen välillä olivat pienempiä kuin useissa ulkomaisissa vertailuissa (esim. van Elsen 2000, Hald 1999). Tämä johtunee siitä, että käytimme rikkakasvien yksilömäärää kovariaattina kovarianssianalyysissä, jolloin lajimääriä vertailtiin tilanteessa, jossa yksilömäärät olisivat olleet ikään kuin samansuuruisia. Ulkomaisissakin vertailuissa on rikkakasvien yksilömäärän havaittu olleen huomattavasti korkeampi luomupelloilla tavanomaisiin verrattuna, mutta yksilömäärää ei ole sisällytetty lajimäärän analysointiin. Niinpä luomuviljelyn hyödyt rikkakasvien lajimäärän lisääjinä on ehkä yliarvioitu useissa aikaisemmissa tutkimuksissa.

Koska rikkakasvien laji- ja yksilömäärän välillä oli positiivinen riippuvuus, kaikki tekijät jotka vähensivät yksilömäärää alensivat myös lajimäärää. Tavanomaisesti viljellyillä pelloilla käytettiin torjunta-aineita yksilömäärän alentamiseen, sen sijaan luomupelloilla ei käytetty suoria torjuntamenetelmiä. Jos luomupelloilla olisi käytetty suoria torjuntatoimia, viljelymenetelmien erot olisivat olleet todennäköisesti pienempiä. Nyt torjunta-aineiden käyttö piti tavanomaisten peltojen lajimäärän samalla tasolla kasvukauden aikana, kun taas luomupeltojen lajimäärä kohosi kasvukauden myötä. Vuosien myötä suurempi lisääntyvien rikkakasvien yksilömäärä luomupelloilla johtaa suurempaan 
siemenpankin kokoon ja siten suurempaan keväällä itävien siementen määrään. Tämä näkyi tutkimuksessamme luomupeltojen suurempana lajimääränä touko-kesäkuussa.

Muutokset lajien runsaussuhteissa kasvukauden aikana osoittivat, että torjunta-aineiden käyttö alensi niille herkkien lajien (erityisesti jauhosavikan) suhteellista runsautta. Osa lajien suhteellisen runsauden muutoksista voidaan selittää kuitenkin lajien erilaisilla itämisajankohdilla; esimerkiksi pelto-orvokki itää myöhempään ja välttää siten alkukesästä tehtävän torjuntaruiskutuksen. Vaikka runsaimmat lajit olivat molempien viljelymenetelmien pelloilla paljolti samoja, luomupeltojen suuremmat kokonaislajimäärät viittaavat siihen, että luomuviljely suosii lajidiversiteettiä. Lajimäärän ei vaikuta pelkästään torjunta-aineiden käyttö, vaan esimerkiksi myös viljelykierto. Tästä viitteenä oli luomupelloilta tavattu ruiskaunokki, joka esiintyi lohkoilla, joiden viljelykierrossa oli syysviljaa. Luomuviljely näyttää lisäävän lajimäärää jo lyhyessä ajassa, mutta perusteellisempi lajiston koostumuksen muutos vaatii pidempää aikaa, sillä lajien levintä ei tapahdu hetkessä. Luomuviljelyn alkuvaiheessa olevien peltojen rikkakasviyhteisöt muistuttavat lajistoltaan paljolti ruiskuttamatta jääneitä tavanomaisesti viljeltyjä peltoja.

Ruiskutettujen lohkojen vertailu 1980- ja 1990-lukujen välillä osoitti muutosten rikkakasvien määrässä olevan varsin vähäisiä. Kokonaiskuivapainon muutos oli vain noin $30 \mathrm{~kg} / \mathrm{ha}$, ja useimpien lajien runsauden muutokset olivat vähäisiä. Muutokset olivat paljolti ennakko-odotustemme mukaisia: sulfonyyliureoille vastustuskykyisten lajien, pelto-orvokin ja peltomataran, runsauden ja esiintymisfrekvenssien havaittiin kasvaneen. Yllättävintä lajien runsauden muutoksissa oli, että jauhosavikka oli yksi runsastuneista lajeista, vaikka se on herkkä lähes kaikille käytetyille torjunta-aineille. Tämä saattaa johtua tutkimusvuosien välisestä sääolosuhteiden vaihtelusta. Tutkimusvuosista 1997 ja 1999 olivat lämpimiä sekä kuivia ja vuosi 1998 kostea. Kuivat kesät suosivat jauhosavikkaa ja toisaalta kosteat olot johtavat usein torjunnan epäonnistumiseen tai torjunta jää kokonaan tekemättä. Yllättävää oli myös, etteivät taustamuuttujat pystyneet selittämään peltolohkojen välistä vaihtelua rikkakasvien runsaudessa. Tämä saattaa johtua siitä, että lähes kaikkien taustamuuttujien tiedot olivat käytössä ainoastaan tutkimusvuoden osalta. Siten ne eivät pystyneet kuvaamaan kartoitusten välillä tapahtuneita muutoksia. Toisaalta keskeisin tutkimuspelloilla tapahtunut muutos vuosikymmenten välillä käytettyjen taustamuuttujien perusteella oli nimenomaan muutos torjunta-aineiden käytössä, ja aikaisempien tutkimusten perusteella tiedetään, että torjunta-aineiden käyttö on tärkein kevätviljapeltojen rikkakasvien lajiston koostumuksen vaikuttava tekijä (Salonen 1993).

\section{Johtopäätökset}

Kevätviljapeltojen rikkakasvien runsaudessa havaittiin vain vähäisiä muutoksia 1980- ja 1990-lukujen välillä. Luomuviljely näyttää lisäävän rikkakasvien lajimäärää jo alkuvaiheessa, mutta lajiston koostumus luomun alkuvaiheen pelloilla muistuttaa paljolti torjunta-aineella käsittelemättömiä tavanomaisesti viljeltyjä peltoja. Lajiston koostumuksen muuttuminen vaatii ilmeisesti pidemmän ajan luomuviljelyä kuin mitä tutkimustiloilla oli harjoitettu. Tavanomaisesti viljellyillä kevätviljapelloilla rikkakasvien runsaus oli hieman kasvanut. Torjunta-aineiden käytön muutos heijastui rikkakasvilajistoon.

\section{Kirjallisuus}

van Elsen, T. 2000. Species diversity as a task for organic agriculture in Europe. Agric. Ecos. Env. 77: 101109.

Erviö, L-R. \& Salonen, J. 1987. Changes in the weed population of spring cereals in Finland. Ann. Agric. Fenn. 26: 210-226.

Hald, A.B. 1999. Weed vegetation (wild flora) of long established organic versus conventional cereal fields in Danmark. Ann. appl. Biol. 134: 307-314.

Mukula, J., Raatikainen, M., Lallukka, R. \& Raatikainen, T. 1969. Composition of weed flora in spring cereals in Finland. Ann. Agric. Fenn. 8: 59-109.

Salonen, J. 1993. Weed infestation and factors affecting weed incidence in spring cereals in Finland - a multivariate approach. Agric. Sci. Finl. 2: 525-536.

Salonen, J., Hyvönen, T. \& Jalli, H. 2001. Weeds in spring cereal fields in Finland - a third survey. Agric. Food. Sci. Finl. (painossa). 